\title{
PENGARUH DISIPLIN KERJA DAN BEBAN KERJA TERHADAP KINERJA KARYAWAN (STUDI PADA KARYAWAN PT ISS INDONESIA)
}

\author{
Tine Yuliantini ${ }^{1^{*}}$, Suryatiningsih ${ }^{1}$ \\ ${ }^{1}$ Program Studi Manajemen, Fakultas Ekonomi dan Bisnis \\ Universitas Mercu Buana \\ Email: tine.yuliantini@mercubuana.ac.id, suryatiningsih020@gmail.com \\ *Korespondensi:tine.yuliantini@mercubuana.ac.id
}

(Submission 03-08-2021, Revissions 09-09-2021, Accepted 15-09-2021)

\begin{abstract}
This study aimed to identify and analyze the effect of work discipline and workload on employee performance. The research method used in this research is causal research. The object of this research are 60 employees of PT ISS Indonesia. The data analysis methods used in this research are SPSS and Partial Least Square (PLS). The results showed that work discipline has a positive and significant effect on the employee performance of PT ISS Indonesia with an original sample score 0,558 and T-Statistic 4,252>1.96. Workload has a positive and significant effect on the employee performance of PT ISS Indonesia with an original sample score 0,313 and T-Statistic 2,377> 1.96 .
\end{abstract}

Keywords: human resource management, organizational behavior, work discipline, workload, employee performance.

\begin{abstract}
Abstrak
Penelitian ini bertujuan untuk mengetahui dan menganalisis pengaruh disiplin kerja dan beban kerja terhadap kinerja. Metode penelitian yang digunakan dalam penelitian ini adalah penelitian kausal. Objek penelitian ini adalah 60 karyawan PT ISS Indonesia. Metode analisis data yang digunakan dalam penelitian ini adalah SPSS dan Partial Least Square (PLS). Hasil penelitian menunjukkan bahwa disiplin kerja berpengaruh positif dan signifikan terhadap kinerja karyawan PT ISS Indonesia dengan nilai original sample 0,558 dan TStatistic 4,252>1,96. Beban kerja berpengaruh positif dan signifikan terhadap kinerja karyawan PT ISS Indonesia dengan nilai original sample 0,313 dan T-Statistic 2,377 > 1,96.
\end{abstract}

Kata Kunci: manajemen sumber daya manusia, perilaku organisasi, disiplin kerja, beban kerja, kinerja karyawan.

\section{PENDAHULUAN}

Sumber daya manusia merupakan salah satu sumber daya yang paling menentukan sukses tidaknya suatu organisasi. Sumber daya manusia berperan 
penting dalam setiap kegiatan perusahaan. Sumber daya manusia dapat menentukan keberhasilan pelaksanaan kegiatan perusahaan. Perusahaan dibentuk untuk mencapai tujuan tertentu dan apabila tercapai maka bisa dapat dikatakan berhasil (Giovanni et al., 2015; Hoki dan Sofyan, 2019).

Penelitian terdahulu menyebutkan bahwa berhasil atau tidaknya suatu organisasi atau instansi akan ditentukan oleh faktor manusianya atau karyawan dalam pencapaian tujuannya. Karyawan dapat bekerja dengan baik bila memiliki kinerja yang tinggi sehingga dapat menghasilkan kerja yang baik pula. Kemajuan suatu perusahaan juga sangat ditentukan oleh kualitas sumber daya manusia, khususnya kinerja. Karena itu, untuk mengatasi persaingan dan mencapai keunggulan kompetitif, suatu organisasi membutuhkan individu-individu yang memiliki perilaku standar kerja dengan menghasilkan, mempromosikan dan memberikan ide-ide baru bagi organisasi. Seorang karyawan yang memiliki kinerja yang tinggi dan baik dapat menunjang tercapainya tujuan dan sasaran yang telah ditetapkan (Yudiningsih et al., 2016; Salwa et al., 2018).

Penelitian berikut juga menyebutkan bahwa setiap perusahaan pasti menuntut kinerja yang terbaik yang mampu dilakukan oleh setiap karyawannya. Kinerja yang baik tentunya diiringi sumber daya manusia yang baik pula dan diterapkan metode yang membantu sebagai pendorong pencapai tujuan target perusahaan. Penciptaan sumber daya manusia yang baik dibangun oleh sikap disiplin kerja yang tinggi dalam diri karyawan sehingga perbuatan untuk selalu mentaati tata tertib, memiliki perhatian besar terhadap pekerjaan dan lingkungan kerja. Dengan demikian, disiplin kerja berpengaruh positif dan signifikan terhadap kinerja karyawan (Soelton dan Rahmi, 2016; Yamanie et al., 2016; Giwangkara dan Winarno, 2019).

Penelitian Arianto (2013) menunjukkan hal berbeda, dimana hasil penelitian menyatakan bahwa kedisiplinan kerja tidak berpengaruh terhadap kinerja. Begitu pula penelitian Kurniasari (2014) yang mengungkapkan bahwa disiplin kerja tidak berpengaruh signifikan terhadap kinerja. Ini berbeda dengan penelitian Adityawarman et al. (2015) yang mengemukakan bahwa beban kerja berpengaruh positif dan signifikan terhadap kinerja karyawan. Demikian pula dengan penelitian (Irawati dan Carollina, 2017), bahwa beban kerja secara internal berpengaruh positif terhadap kinerja karyawan. Hasil berbeda juga terdapat pada penelitian Kusuma dan Soesatyo (2014) dan Sukaini et al., (2018), yang menyatakan bahwa beban kerja berpengaruh negatif dan signifikan terhadap kinerja karyawan.

PT ISS Indonesia telah menempatkan karyawannya di Universitas Mercu Buana. Berdasarkan tanggapan dan saran dari atasan karyawan PT ISS Indonesia yang ditempatkan di Universitas Mercu Buana, diberikan pernyataan penilaian bahwa karyawan perlu untuk meningkatkan kualitas kerja, konsisten dalam bekerja dan mempelajari SOP (Standar Operasional Prosedur). Pernyataan penilaian ini, menurut peneliti menunjukkan bahwa masih banyak karyawan yang kinerjanya harus diperbaiki dan ditingkatkan baik dalam hal etika, penggunaan mesin/peralatan dan SOP (Standar Operasional Prosedur). Penilaian karyawan selama ini dilakukan secara langsung dan mengikuti standar PT ISS Indonesia. 
Dengan adanya perbedaan pada hasil penelitian terdahulu, maka penelitian ini dilakukan untuk menguji hubungan disiplin kerja dan beban kerja karyawan terhadap kinerja karyawan dengan pokok pertanyaan yang diajukan adalah: Apakah disiplin kerja berpengaruh terhadap kinerja karyawan, dan Apakah beban kerja berpengaruh pada kinerja karyawan.

\section{Definisi dan Konsep}

Perilaku Organisasi (Organizational Behavior) adalah suatu bidang studi yang menginvestasi pengaruh individu, kelompok, dan struktur terhadap perilaku di dalam organisasi, untuk tujuan penerapan pengetahuan demi peningkatan efektivitas organisasi. Perilaku organisasi juga merupakan suatu studi yang menyangkut aspekaspek tingkah laku manusia dalam suatu organisasi atau suatu kelompok tertentu. Selain itu, perilaku organisasi adalah kajian ilmu tentang individu-individu untuk mendapatkan informasi mengenai kebiasaan, tingkah laku, cara kerja, dan berbagai dinamika dampak keterlibatan individu di dalam suatu organisasi (Robbins dan Judge, 2015; Mustapa, 2018; Duha, 2018).

Dengan demikian dapat disimpulkan bahwa perilaku organisasi adalah suatu bidang studi yang mempelajari pengaruh individu, kelompok dan struktur terhadap perilaku dalam organisasi untuk mendapatkan informasi mengenai berbagai dinamika keterlibatan individu di dalam organisasi untuk tujuan efektivitas organisasi.

Kinerja dirumuskan sebagai hasil dari suatu proses yang mengacu dan diukur selama periode waktu tertentu berdasarkan ketentuan atau kesepakatan yang telah ditetapkan sebelumnya. Selain itu, pengertian kinerja/prestasi kerja adalah hasil kerja yang dapat dicapai oleh seseorang atau kelompok orang dalam suatu perusahaan sesuai dengan wewenang dan tanggung jawab masing-masing dalam upaya pencapaian tujuan organisasi secara legal, tidak melanggar hukum dan tidak bertentangan dengan moral dan etika (Edison, 2016; Afandi, 2016).

Dimensi dan indikator kinerja karyawan yang digunakan dalam penelitian ini adalah berdasarkan teori yang dirumuskan Afandi (2016), yaitu:

1. Dimensi hasil kerja yang terdiri dari tiga indikator yaitu:
a) Kuantitas hasil kerja
b) Kualitas hasil kerja
c) Efisiensi dalam melaksanakan tugas

2. Perilaku kerja yang terdiri dari tiga indikator yaitu:
a) Disiplin kerja
b) Inisiatif
c) Ketelitian

3. Sifat pribadi yang terdiri dari tiga indikator yaitu:
a) Kepemimpinan
b) Kejujuran
c) Kreativitas 
Disiplin kerja didefinisikan sebagai suatu tata tertib atau peraturan yang dibuat oleh manajemen suatu organisasi, disahkan oleh dewan komisaris atau pemilik modal, disepakati oleh serikat pekerja dan diketahui oleh Dinas Tenaga Kerja, dimana orang-orang yang tergabung dalam organisasi tunduk pada tata tertib yang ada dengan rasa senang hati. Disiplin kerja juga diartikan sebagai pelaksanaan manajemen untuk memperteguh pedoman-pedoman organisasi (Afandi, 2016; Davis, 1985 dalam Mangkunegara, 2016).

Disiplin sendiri menunjukkan suatu kondisi atau sikap hormat yang ada pada diri karyawan terhadap peraturan dan ketetapan perusahaan. Jika peraturan atau ketetapan yang ada dalam perusahaan diabaikan, atau sering dilanggar, hal tersebut yang menyebabkan karyawan mempunyai disiplin yang buruk. Namun jika karyawan taat pada ketetapan perusahaan, menggambarkan kondisi disiplin yang baik. Sedangkan kedisiplinan adalah kesadaran dan kesediaan seseorang mentaati semua peraturan perusahaan dan norma-norma sosial yang berlaku (Sutrisno, 2018; Hasibuan 2012). Afandi (2016), merumuskan dimensi dan indikator disiplin kerja sebagai berikut:

1. Dimensi ketaatan waktu, dengan indikator:
a) Masuk kerja tepat waktu
b) Penggunaan waktu secara efektif
c) Tidak pernah mangkir/tidak kerja

2. Dimensi tanggung jawab kerja, dengan indikator sebagai berikut:

a) Mematuhi semua peraturan organisasi atau perusahaan

b) Target pekerjaan

c) Membuat laporan kerja harian

Beban kerja adalah suatu kemampuan tubuh dalam menerima pekerjaan. Beban kerja juga diartikan sebagai satu kondisi dari pekerjaan dengan uraian tugasnya yang harus diselesaikan pada batas waktu tertentu (Ambarwati, 2014; Munandar, 2014). Peraturan Menteri Dalam Negeri Nomor 12 Tahun 2008, menyatakan bahwa beban kerja adalah besaran pekerjaan yang harus dipikul oleh suatu jabatan/unit organisasi dan merupakan hasil kali antara volume kerja dan norma waktu. Adapun dimensi dan indikator beban kerja meliputi:

1. Tuntutan fisik

a) Kondisi kesehatan fisik

b) Kondisi mental karyawan

c) Kondisi psikologi karyawan

2. Tuntutan tugas

a) Beban kerja terlalu banyak/sedikit kuantitatif

b) Beban kerja berlebihan/terlalu sedikit kualitatif

\section{Kerangka Pemikiran}

Kerangka pemikiran yang dikembangkan pada penelitian ini bisa digambarkan sebagai berikut: 


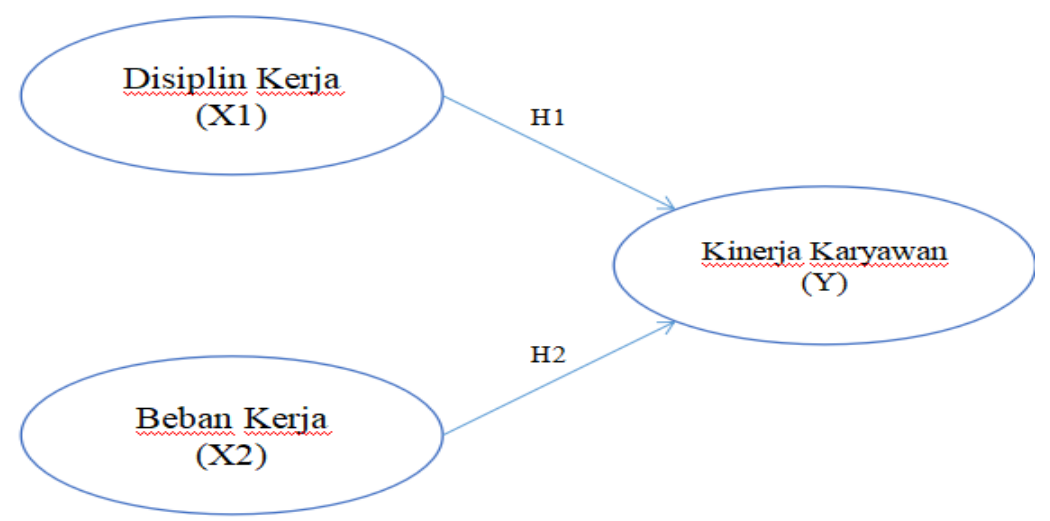

Gambar 1. Kerangka Konseptual

Kerangka pemikiran dengan model hubungan antara masing-masing variabel sebagaimana Gambar 1, maka hipotesis yang diajukan pada penelitian ini adalah:

H1: Disiplin kerja berpengaruh terhadap kinerja karyawan.

$\mathrm{H} 2$ : Beban kerja berpengaruh terhadap kinerja karyawan.

Penelitian ini bertujuan untuk mengetahui pengaruh Disiplin Kerja dan Beban Kerja terhadap Kinerja Karyawan PT ISS Indonesia yang ditempatkan di Mercua Buana, dan untuk mengetahui pengaruh beban kerja terhadap kinerja karyawan PT ISS Indonesia yang ditempatkan di Mercu Buana. Selain itu hasil penelitian juga diharapkan bisa memberikan saran positif bagi PT ISS Indonesia.

\section{METODE PENELITIAN}

Desain penelitian yang digunakan adalah penelitian kausal dengan pendekatan kuantitatif. Dalam penelitian ini yang menjadi populasi adalah karyawan PT ISS Indonesia yang ditempatkan di Universitas Mercu Buana periode 2020 (sebelum kontrak kerjasama berakhir) sebanyak 60 orang. Jumlah sampel yang digunakan dalam penelitian ini menggunakan sampel jenuh. Metode analisis data yang digunakan Component atau Variance Based Structural Equation Modeling dimana pengolahan datanya menggunakan program Partial Least Square (SmartPLS $3.0)$.

\section{HASIL DAN PEMBAHASAN}

\section{Uji Validitas}

Uji validitas digunakan untuk mengukur sah atau valid tidaknya suatu kuesioner dalam seberapa baik tingkat kemapanan, ketepatan, dan kecermatan yang digunakan dalam suatu pengukuran, dengan cara membanding nilai korelasi atau $r$ hitung dengan $\mathrm{r}$ tabel. Dengan rumus degree of freedom $(\mathrm{df})=\mathrm{n}-\mathrm{k}$, dimana $\mathrm{n}$ merupakan jumlah sampel yang digunakan dan $\mathrm{k}$ merupakan jumlah variabel yang digunakan (Ghozali, 2018; Sugiyono, 2017). 
Dalam penelitian ini nilai $\mathrm{n}$ adalah 30 orang dan nilai $\mathrm{k}$ adalah 3. Maka df $=$ 30-3 = 27. Dengan df $=27$ dan pada taraf signifikansi 95\% $(\alpha=0,05)$ dan didapat $r-$ tabel dua sisi adalah 0,367. Jika r-hitung > r-tabel maka pernyataan dikatakan valid. Sebaliknya, jika nilai r-hitung < r-tabel maka butir pernyataan tidak valid.

Tabel 1

Hasil Uji Validitas Variabel Kinerja Karyawan

\begin{tabular}{|c|c|c|c|}
\hline Indikator & r hitung & r tabel & Keterangan \\
\hline KK1 & 0,870 & 0,367 & Valid \\
\hline KK2 & 0,922 & 0,367 & Valid \\
\hline KK3 & 0,922 & 0,367 & Valid \\
\hline KK4 & 0,909 & 0,367 & Valid \\
\hline KK5 & 0,689 & 0,367 & Valid \\
\hline KK6 & 0,903 & 0,367 & Valid \\
\hline KK7 & 0,841 & 0,367 & Valid \\
\hline KK8 & 0,811 & 0,367 & Valid \\
\hline KK9 & 0,736 & 0,367 & Valid \\
\hline
\end{tabular}

Hasil uji validitas pada Tabel 1 menunjukkan bahwa keseluruhan indikator variabel kinerja karyawan mempunyai nilai r-hitung $>$ r-tabel. Maka dapat disimpulkan bahwa keseluruhan indikator variabel kinerja karyawan adalah valid.

Tabel 2

Hasil Uji Validitas Variabel Disiplin Kerja

\begin{tabular}{|c|c|c|c|}
\hline Indikator & $\mathbf{r}$ hitung & $\mathbf{r}$ tabel & Keterangan \\
\hline DK1 & 0,700 & 0,367 & Valid \\
\hline DK2 & 0,762 & 0,367 & Valid \\
\hline DK3 & 0,494 & 0,367 & Valid \\
\hline DK4 & 0,766 & 0,367 & Valid \\
\hline DK5 & 0,781 & 0,367 & Valid \\
\hline DK6 & 0,760 & 0,367 & Valid \\
\hline
\end{tabular}

Hasil uji validitas pada Tabel 2, memperlihatkan bahwa keseluruhan indikator variabel disiplin kerja mempunyai nilai r-hitung > r-tabel. Maka dapat disimpulkan bahwa keseluruhan indikator variabel disiplin kerja adalah valid. 
Tabel 3

Hasil Uji Validitas Variabel Beban Kerja

\begin{tabular}{|c|c|c|c|}
\hline Indikator & r hitung & r tabel & Keterangan \\
\hline BK1 & 0,849 & 0,367 & Valid \\
\hline BK2 & 0,846 & 0,367 & Valid \\
\hline BK3 & 0,849 & 0,367 & Valid \\
\hline BK4 & 0,707 & 0,367 & Valid \\
\hline BK5 & 0,733 & 0,367 & Valid \\
\hline
\end{tabular}

Pada hasil uji validitas pada Tabel 3, dapat dilihat bahwa keseluruhan indikator variabel beban kerja mempunyai nilai r-hitung > r-tabel. Maka dapat disimpulkan bahwa keseluruhan indikator variabel beban kerja adalah valid.

\section{Uji Reliabilitas}

Ghozali (2018) menyebutkan bahwa reliabilitas adalah alat untuk mengukur suatu kuesioner yang merupakan indikator dari variabel atau konstruk. Suatu kuesioner dapat dikatakan reliabel atau andal apabila jawaban responden terhadap pertanyaan dalam kuesioner konsisten atau stabil dari waktu ke waktu. Uji reliabilitas dilakukan dengan melihat nilai Cronbach's Alpha. Jika cronbach's alpha lebih besar dari 0,60, maka suatu instrumen dikatakan reliabel, sebaliknya jika lebih kecil dari 0,60 maka dikatakan tidak reliabel. Hasil uji reliabilitas setiap variabel dalam penelitian ini menunjukkan:

Tabel 4

Hasil Uji Reliabilitas

\begin{tabular}{|l|c|c|c|c|}
\hline \multicolumn{1}{|c|}{ Variabel } & N of items & $\begin{array}{c}\text { Cronbach's } \\
\text { Alpha }\end{array}$ & Kriteria & Keterangan \\
\hline Kinerja Karyawan & 9 & 0,948 & $>0,60$ & Reliabel \\
\hline Disiplin Kerja & 6 & 0,716 & $>0,60$ & Reliabel \\
\hline Beban Kerja & 5 & 0,852 & $>0,60$ & Reliabel \\
\hline
\end{tabular}

Hasil uji relibilitas pada Tabel 4 memperlihatkan bahwa semua variabel mempunyai nilai cronbach's alpha $>0,60$ yang artinya semua variabel yang diteliti sudah reliabel, sehingga dapat dikatakan alat ukur yang digunakan mempunyai hasil yang konsisten dan dapat digunakan dalam penelitian ini.

\section{Evaluasi Outer Model}

Campbell dan Fiske (1959) dalam Ghozali dan Latan (2015) menyebutkan bahwa cara yang sering digunakan peneliti untuk melakukan pengukuran model adalah dengan menguji validitas convergent dan discriminant. 


\section{1) Convergent Validity}

Ghozali dan Latan (2015) menyebutkan bahwa uji validitas convergent indikator refleksif dengan program SmartPLS 3.0 dapat dilihat dari nilai loading factor untuk tiap indikator konstruk. Menurut Chin (1998) dalam Ghozali dan Latan (2015), suatu indikator dikatakan valid yang baik jika nilainya lebih besar dari 0,70 ; sedangkan loading factor 0,50 sampai 0,60 dapat dianggap cukup. Berdasarkan kriteria tersebut bila ada loading factor di bawah 0,50 maka akan didrop dari model.

Dengan melihat hasil output, korelasi antara indikator dengan konstruk pada penelitian ini menunjukkan hasil sebagai ditunjukkan pada Tabel 5, dengan korelasi sebagaimana Gambar 2.

Tabel 5

Hasil Uji Convergent Validity

\begin{tabular}{|c|c|c|c|}
\hline Variabel & Indikator & Outer Loading & Keterangan \\
\hline \multirow{5}{*}{ Kinerja Karyawan (Y) } & KK1 & 0,785 & Valid \\
\cline { 2 - 4 } & KK2 & 0,769 & Valid \\
\cline { 2 - 4 } & KK3 & 0,916 & Valid \\
\cline { 2 - 4 } & KK4 & 0,874 & Valid \\
\cline { 2 - 4 } & KK5 & 0,839 & Valid \\
\cline { 2 - 4 } & KK6 & 0,861 & Valid \\
\cline { 2 - 4 } & KK7 & 0,569 & Valid \\
\cline { 2 - 4 } & KK8 & 0,793 & Valid \\
\cline { 2 - 4 } & KK9 & 0,793 & Valid \\
\hline \multirow{5}{*}{ Disiplin Kerja (X1) } & DK2 & 0,668 & Valid \\
\cline { 2 - 4 } & DK4 & 0,800 & Valid \\
\cline { 2 - 4 } & DK5 & 0,906 & Valid \\
\cline { 2 - 4 } & DK6 & 0,891 & Valid \\
\hline \multirow{5}{*}{ Beban Kerja (X2) } & BK1 & 0,684 & Valid \\
\cline { 2 - 4 } & BK2 & 0,868 & Valid \\
\cline { 2 - 4 } & BK3 & 0,759 & Valid \\
\cline { 2 - 4 } & BK4 & 0,657 & Valid \\
\cline { 2 - 4 } & BK5 & 0,786 & Valid \\
\hline
\end{tabular}




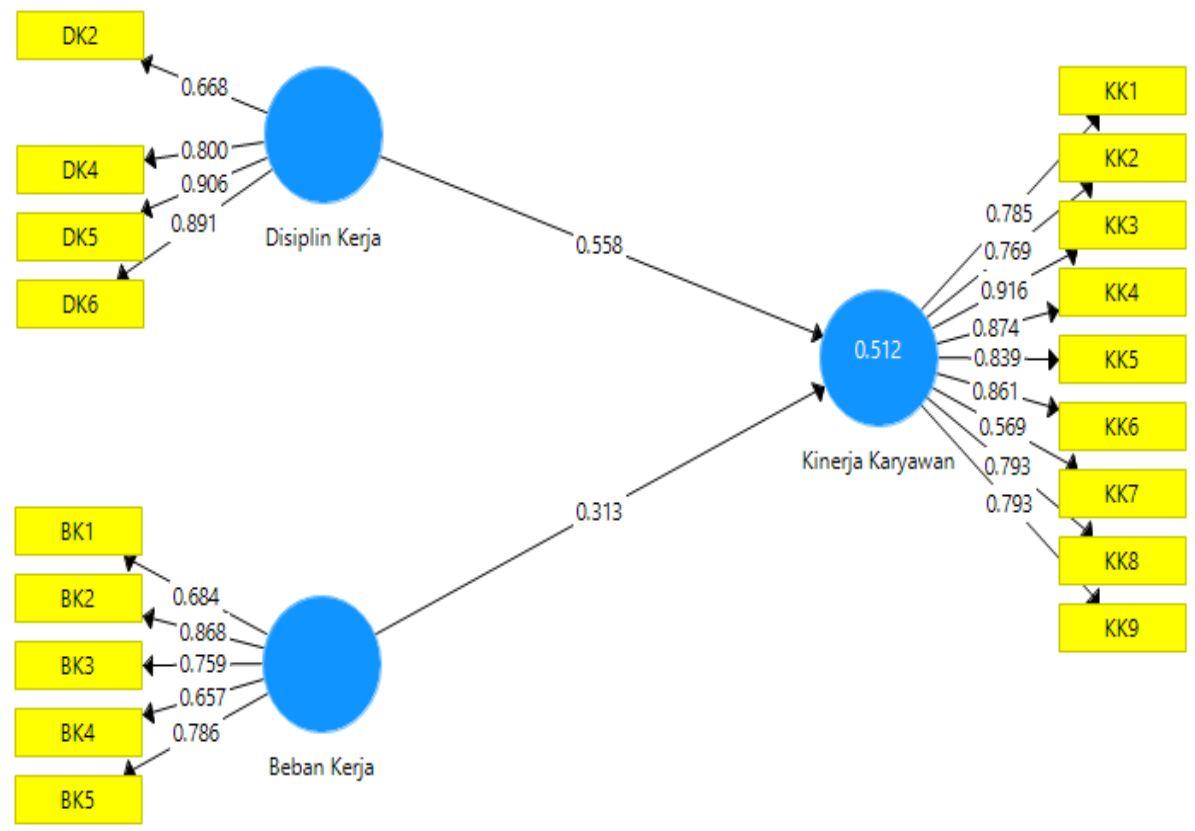

\section{Gambar 2 Hasil Uji Convergent Validity (Modifikasi}

Tabel 5 dan Gambar 2 memperlihatkan bahwa semua indikator telah memenuhi convergent validity (data telah valid) karena memiliki nilai loading factor di atas 0,50 .

2) Discriminant Validity.

Ghozali (2014) menyebutkan bahwa pengujian discriminant validity dinilai berdasarkan cross loading antara indikator dengan konstruknya. Suatu indikator dinyatakan valid jika mempunyai loading factor tertinggi kepada konstruk yang dituju dibandingkan loading factor kepada konsruk lain. Hasil uji discriminant validity pada penelitian ini menujukkan sebagai berikut:

Tabel 6

Hasil Uji Discriminant Validity (Cross Loadings)

\begin{tabular}{|c|c|c|c|}
\hline & $\begin{array}{c}\text { Disiplin Kerja } \\
(\mathrm{X} 1)\end{array}$ & $\begin{array}{c}\text { Beban Kerja } \\
(\mathrm{X} 2)\end{array}$ & $\begin{array}{c}\text { Kinerja Karyawan } \\
(\mathrm{Y})\end{array}$ \\
\hline DK2 & 0,668 & 0,326 & 0,398 \\
\hline DK4 & 0,800 & 0,300 & 0,570 \\
\hline DK5 & 0,906 & 0,162 & 0,530 \\
\hline DK6 & 0,891 & 0,198 & 0,605 \\
\hline BK1 & 0,117 & 0,684 & 0,126 \\
\hline BK2 & 0,235 & 0,868 & 0,322 \\
\hline
\end{tabular}




\begin{tabular}{|c|c|c|c|}
\hline & $\begin{array}{c}\text { Disiplin Kerja } \\
(\mathrm{X} 1)\end{array}$ & $\begin{array}{c}\text { Beban Kerja } \\
(\mathrm{X} 2)\end{array}$ & $\begin{array}{c}\text { Kinerja Karyawan } \\
(\mathrm{Y})\end{array}$ \\
\hline BK3 & 0,165 & 0,759 & 0,244 \\
\hline BK4 & 0,212 & 0,657 & 0,323 \\
\hline BK5 & 0,271 & 0,786 & 0,525 \\
\hline KK1 & 0,639 & 0,374 & 0,785 \\
\hline KK2 & 0,721 & 0,255 & 0,769 \\
\hline KK3 & 0,522 & 0,481 & 0,916 \\
\hline KK4 & 0,514 & 0,416 & 0,874 \\
\hline KK5 & 0,417 & 0,391 & 0,839 \\
\hline KK6 & 0,459 & 0,391 & 0,861 \\
\hline KK7 & 0,465 & 0,397 & 0,569 \\
\hline KK8 & 0,393 & 0,421 & 0,793 \\
\hline KK9 & 0,445 & 0,317 & 0,793 \\
\hline
\end{tabular}

Tabel 6 memperlihatkan bahwa korelasi konstruk Disiplin Kerja dengan indikator DK2, DK4, DK5 dan DK6 lebih tinggi dibandingkan korelasi dengan konstruk lainnya (Beban Kerja dan Kinerja Karyawan). Kemudian korelasi konstruk Beban Kerja dengan indikator BK1, BK2, BK3, BK4 dan BK5 lebih tinggi dibandingkan korelasi dengan konstruk lainnya (Disiplin Kerja dan Kinerja Karyawan). Lalu, korelasi konstruk Kinerja Karyawan dengan indikator KK1, KK2, KK3, KK4, KK5, KK6, KK7, KK8 dan KK9 lebih tinggi dibandingkan korelasi dengan konstruk lainnya (Disiplin Kerja dan Beban Kerja).

Tabel 7

Hasil Uji Discriminat Validity (AVE)

\begin{tabular}{|c|c|}
\hline Variabel & Average Variance Extracted $(\boldsymbol{A}$ VE) \\
\hline Kinerja Karyawan & 0,649 \\
\hline Disiplin Kerja & 0,676 \\
\hline Beban Kerja & 0,569 \\
\hline
\end{tabular}

Fornell dan Larcker (1981) dalam Ghozali dan Latan (2015) menyebutkan bahwa metode lain untuk melihat discriminant validity adalah dengan melihat square root of average variance extracted $(A V E)$ setiap konstruk dengan korelasi antara konstruk relasi dengan konstruk lainnya dalam model. Discriminant validity yang baik ditunjukkan dari nilai $A V E$ untuk masing-masing konstruk nilainya lebih besar dari 0,50 dan discriminant validity yang baik ditunjukkan dari akar kuadrat $A V E$ untuk tiap konstruk lebih besar dari korelasi antar konstruk dalam model. Hasil uji discriminant validity dengan melihat $A V E$ pada penelitian, seperti pada tabel 7:

Tabel 7 menunjukkan hasil output AVE untuk konstruk Disiplin Kerja, Beban Kerja dan Kinerja Karyawan lebih besar dari 0,50. Untuk Kinerja Karyawan 
memiliki nilai $A V E$ 0,649 >0,50; Disiplin Kerja memiliki nilai $A V E 0,676>0,50$ dan Beban Kerja memiliki nilai $A V E$ 0,569 > 0,50. Maka, seluruh konstruk telah memiliki discriminant vaidity yang baik.

\section{Tabel 8}

Hasil Pengujian Discriminant Validity (Fornell Larcker Criterium)

\begin{tabular}{|l|c|r|r|}
\hline & \multicolumn{1}{|c|}{$\begin{array}{c}\text { Kinerja } \\
\text { Karyawan }\end{array}$} & Disiplin Kerja & Beban Kerja \\
\hline Kinerja Karyawan & 0,805 & 0,649 & 0,476 \\
\hline Disiplin Kerja & & 0,822 & 0,291 \\
\hline Beban Kerja & & & 0,755 \\
\hline
\end{tabular}

Tabel 8 menunjukkan bahwa akar kuadrat dari $A V E$ untuk setiap konstruk lebih besar daripada korelasi antara konstruk yang satu dengan konstruk lainnya dalam model. Maka berdasarkan tabel di atas, juga menunjukkan bahwa konstruk dalam model yang diestimasi memenuhi kriteria discriminant validity.

3) Composite Reliability dan Cronbach's Alpha

Ghozali (2014) menyebutkan bahwa pengujian composite reliability bertujuan untuk menguji reliabilitas instrumen dalam suatu model penelitian. Apabila seluruh nilai variabel laten memiliki nilai composite reliability maupun cronbach's alpha $\geq 0,7$ hal ini berarti bahwa konstruk memiliki reliabilitas yang baik atau kuesioner yang digunakan sebagai alat dalam penelitian telah andal atau konsisten. Hasil pengujian composite reliability maupun cronbach's alpha pada penelitian ini, pada tabel 9:

Tabel 9

Composite Reliability dan Cronbach's Alpha

\begin{tabular}{|l|c|c|}
\hline & Composite Reliability & Cronbach's Alpha \\
\hline Kinerja Karyawan & 0,942 & 0,930 \\
\hline Disiplin Kerja & 0,892 & 0,836 \\
\hline Beban Kerja & 0,867 & 0,828 \\
\hline
\end{tabular}

Tabel 9 memperlihatkan bahwa hasil pengujian composite reliability dan cronbach's alpha menunjukan nilai yang memuaskan, karena seluruh variabel laten memiliki nilai composite reliability dan cronbach's alpha $\geq 0,70$. Hal ini berarti seluruh variabel laten dikatakan reliabel.

\section{Evaluasi Inner Model}

1) Nilai R-square 
Tabel 10

Hasil Uji Nilai R-Square

\begin{tabular}{|l|l|}
\hline & $R$-Square \\
\hline Kinerja Karyawan & 0,512 \\
\hline
\end{tabular}

Model struktural mengindikasi bahwa model pada variabel kinerja karyawan dan kinerja organisasi dapat dikatakan moderat. Chin (1998) dalam Ghozali dan Latan (2015) menatakan bahwa nilai $R$-Square di antara 0,33 dan 0,67 termasuk ke dalam kategori moderate. Dengan demikian model pada variabel kinerja karyawan dapat dikatakan moderat karena memiliki nilai antara 0,33 dan 0,67. Model pengaruh variabel laten independen (disiplin kerja dan beban kerja) terhadap kinerja karyawan memberikan nilai $R$-Square sebesar 0,512 sebagaimana ditunjukkan pada Tabel 10 yang dapat diinterpretasikan bahwa variabilitas konstruk kinerja karyawan yang dapat dijelaskan oleh variabilitas konstruk disiplin kerja dan beban kerja sebesar 51,2\% sedangkan 48,8\% dijelaskan oleh variabel lain yang tidak diteliti dalam model ini.

\section{2) Goodness of Fit Model}

Pengujian Goodness of Fit Model structural pada inner model menggunakan nilai predictive-relevance $\left(\mathrm{Q}^{2}\right)$. Nilai $Q$-Square lebih besar dari nol menunjukkan bahwa model mempunyai nilai predictive relevance. Nilai predictive relevance diperoleh dengan rumus:

$$
\begin{aligned}
\mathrm{Q}^{2} & =1-\left(1-\mathrm{R} 1^{2}\right)\left(1-\mathrm{R} 2^{2}\right) \ldots\left(1-\mathrm{Rp}^{2}\right) \\
& =1-(1-0,512) \\
& =0,512
\end{aligned}
$$

Hasil perhitungan di atas memperlihatkan nilai predictive relevance sebesar 0,512 yaitu lebih besar 0 (nol). Hal itu berarti bahwa 51,2\% variasi pada variabel kinerja karyawan (variabel dependen) dijelaskan oleh variabel independen yang digunakan (disiplin kerja dan beban kerja). Dengan demikian model dikatakan layak memiliki nilai prediktif yang relevan.

3) Hasil Pengujian Hipotesis (Estimasi Koefisien Jalur)

Nilai signifikansi pada penelitian ini diperoleh dengan prosedur bootstrapping. Melihat signifikansi pada hipotesis adalah dengan melihat nilai koefisen parameter dan nilai signifikansi T-statistic pada algorithm bootstrapping report, yang disebut signifikan jika T-statistic lebih besar dari 1,96. Selain itu dapat juga dengan melihat $P$-value. Disebut signifikan jika $P$-value lebih kecil dari alpha ( $\alpha$ ) 0,05. Hasil dari bootstrapping menunjukkan: 
Tabel 11

Hasil Uji Hipotesis

\begin{tabular}{|l|c|c|c|c|}
\hline & $\begin{array}{c}\text { Original } \\
\text { Sample }\end{array}$ & T-Statistics & P-Values & Keterangan \\
\hline $\begin{array}{l}\text { Disiplin Kerja } \rightarrow \\
\text { Kinerja Karyawan }\end{array}$ & 0,558 & 4,252 & 0,000 & $\begin{array}{c}\text { Positif- } \\
\text { Signifikan }\end{array}$ \\
\hline $\begin{array}{l}\text { Beban Kerja } \rightarrow \\
\text { Kinerja Karyawan }\end{array}$ & 0,313 & 2,377 & 0,018 & $\begin{array}{c}\text { Positif- } \\
\text { Signifikan }\end{array}$ \\
\hline
\end{tabular}

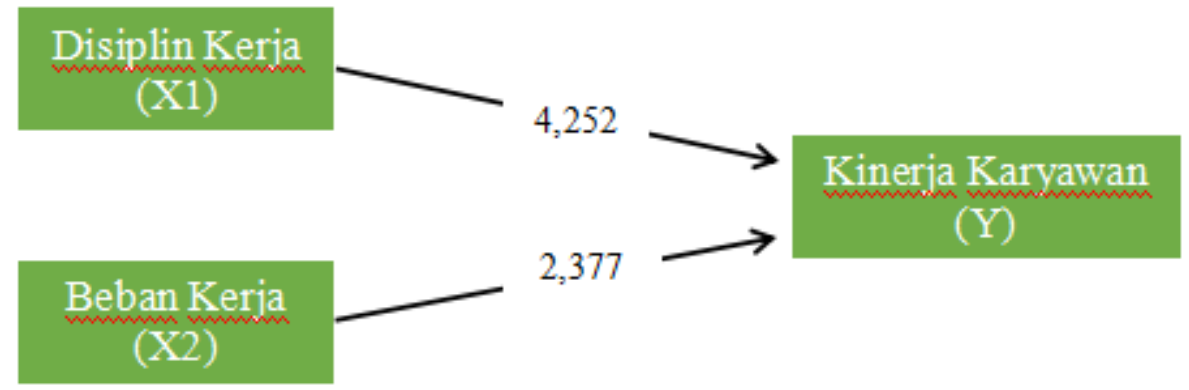

Gambar 3 Hasil Bootsrapping

Berdasarkan hasil pengujian hipotesis (Estimasi Koefisien Jalur) pada Gambar 3, maka bisa dinyatakan:

a) Pengaruh Disiplin Kerja terhadap Kinerja Karyawan

Uji hipotesis yang dilakukan pada Gambar 3 menunjukkan bahwa disiplin kerja berpengaruh positif dan signifikan terhadap kinerja karyawan PT ISS Indonesia. Disiplin Kerja memiliki nilai T-statistic 4,252>T-table pada alpha 5\% $(1,96)$ dan nilai $P$-value $0,000<0,05$. Serta nilai original sample 0,558 maka $\mathrm{H} 1$ diterima yang artinya disiplin kerja berpengaruh positif dan signifikan terhadap kinerja karyawan. Hasil hipotesis ini sejalan dengan penelitian yang pernah dilakukan oleh Soelton dan Rahmi (2016) yang menyatakan bahwa disiplin kerja berpengaruh signifikan terhadap kinerja karyawan. Begitu juga dengan penelitian yang dilakukan oleh Giwangkara dan Winarno (2019) yang menunjukkan bahwa disiplin kerja berpengaruh dan signifikan terhadap kinerja karyawan. Penelitian Yamanie dan Syaharuddin (2016) juga menyatakan bahwa disiplin kerja berpengaruh positif dan signifikan terhadap kinerja karyawan. Dengan demikian bisa dinyatakan bahwa Disiplin Kerja terhadap kinerja karyawan memiliki pengaruh positif dan signifikan. Hal ini menunjukkan bahwa peningkatan disiplin kerja dapat meningkatkan kinerja karyawan. Jika disiplin kerja meningkat, maka dapat membuat karyawan memahami pentingnya kedisiplinan dalam bekerja seperti membuat laporan kerja harian sebagai bentuk disiplin kerja dan selalu melakukan pengawasan, hal tersebut dapat mendorong karyawan untuk melaksanakan target pekerjaan yang diberikan dan menggunakan waktu kerja secara efektif. Hal tersebut dapat membuat kinerja karyawan akan meningkat. 
b) Pengaruh Beban Kerja terhadap Kinerja Karyawan

Uji hipotesis yang dilakukan sebagaimana Gambar 3 menunjukkan bahwa beban kerja berpengaruh positif dan signifikan terhadap kinerja karyawan PT ISS Indonesia. Beban Kerja memiliki nilai T-statistic 2,377> T-table pada alpha 5\% $(1,96)$ dan nilai $P$-value $0,018<0,05$. Serta nilai original sample 0,313 maka $\mathrm{H} 2$ diterima yang artinya beban kerja berpengaruh positif dan signifikan terhadap kinerja karyawan. Hasil hipotesis ini sejalan dengan penelitian Adityawarman et al. (2015) yang mengemukakan bahwa beban kerja berpengaruh positif dan signifikan terhadap kinerja karyawan. Moniharapon (2018) dalam penelitiannya juga mengungkapkan beban kerja mempunyai pengaruh yang signifikan dan positif terhadap kinerja pegawai. Beban kerja terhadap kinerja karyawan yang memiliki pengaruh positif dan signifikan, menunjukkan adanya peningkatan beban kerja yang diberikan kepada karyawan dapat membuat kinerja karyawan meningkat. Untuk memberikan pengaruh yang positif tersebut, tentunya diimbangi dengan melakukan evaluasi dan medical check-up kondisi karyawan secara berkala, melakukan pemetaan kompetensi karyawan berdasarkan job description sehingga beban kerja yang diberikan karyawan sesuai dengan kemampuan dan kompetensi karyawan.

\section{SIMPULAN DAN SARAN}

Hasil penelitian pengaruh disiplin kerja dan beban kerja terhadap kinerja karyawan menunjukkan bahwa disiplin kerja berpengaruh positif dan signifikan terhadap kinerja karyawan PT ISS Indonesia. Hal ini menunjukkan bahwa disiplin kerja tinggi yang dimiliki oleh karyawan dapat meningkatkan kinerja karyawan. Hasil penelitian juga menunjukkan bahwa beban kerja berpengaruh positif dan signifikan terhadap kinerja karyawan PT ISS Indonesia. Hal ini menunjukkan adanya peningkatan beban kerja yang diberikan karyawan dapat meningkatkan kinerja karyawan.

Saran atas hasil penelitian ini, penulis menganjurkan agar PT ISS Indonesia memberikan pengarahan mengenai pentingnya membuat laporan kerja harian sebagai bentuk disiplin kerja dan selalu melakukan pengawasan. Hal ini bisa mendorong karyawan untuk melaksanakan target pekerjaan yang diberikan dan menggunakan waktu kerja secara efektif. Selain itu, selalu melakukan evaluasi dan medical check-up kondisi karyawan secara berkala, melakukan pemetaan kompetensi karyawan berdasarkan job description dapat menjadikan beban kerja yang diberikan karyawan sesuai dengan kemampuan dan kompetensi karyawan.

Saran lain adalah PT ISS Indonesia bisa memberikan masukan dan motivasi kepada karyawan serta melakukan pelatihan dan pengembangan untuk meningkatkan skill karyawan sehingga dapat melakukan pekerjaan secara kreatif yang akan membuat kualitas hasil kerja meningkat dan efisiensi dalam melaksanakan tugas yang diberikan. 


\section{DAFTAR PUSTAKA}

Adityawarman, Yudha,. Sanim, Bunasor,. \& Sinaga, Bonar M. (2015). Pengaruh Beban Kerja terhadap Kinerja Karyawan PT. Bank Rakyat Indonesia (Persero) Tbk Cabang Krekot. Jurnal Manajemen dan Organisasi Vol VI, No 1, April 2015.

Afandi, Pandi. (2016). Concept \& Indicator Human Resources Management for Management Research. Yogyakarta: Deepublish.

Ambarwati, Fitri Respati. (2014). Konsep Kebutuhan Dasar Manusia. Yogyakarta: Dua Satria Offset.

Arianto, Dwi Agung Nugroho. (2013). Pengaruh Kedisiplinan, Lingkungan Kerja dan Budaya Kerja terhadap Kinerja Tenaga Pengajar. Jurnal Economia, Vol 9, No 2.

Duha, Timotius. (2018). Perilaku Organisasi. Yogyakarta: Deepublish.

Edison, E. (2016). Manajemen Sumber Daya Manusia. Bandung: Alfabeta.

Ghozali, Imam. (2014). Structural Equation Modeling - Metode Alternatif dengan Partial Least Squares (PLS). Semarang: Universitas Diponegoro.

Ghozali, Imam. (2018). Aplikasi Analisis Multivariate Dengan Program IBM SPSS 25. Semarang: Badan Penerbit Universitas Diponegoro.

Ghozali, Imam., \& Latan, Hengky. (2015). Partial Least Squares Konsep, Teknik dan Aplikasi Menggunakan Program SmartPLS 3.0 Untuk Penelitian Empiris. Edisi 2. Semarang: Universitas Diponegoro.

Giovanni, Tamauka Marsello., Kojo, Christoffel., \& Lengkong, Victor. P.K. (2015). Pengaruh Konflik Peran, Konflik Kerja dan Stres Kerja Terhadap Kinerja Karyawan Pada PT. Air Manado. Jurnal EMBA Vol.3 No.3 Sept. 2015, Hal. 90-98.

Giwangkara, Natasha Aulia., \& Winarno, Alex. (2019). Pengaruh Disiplin Kerja terhadap Kinerja Karyawan Di PT PLN (Persero) Area Pelayanan Jaringan Bandung. e-Proceeding Of Management : Vol.6, No.1 April 2019 | Page 1070 .

Hasibuan, Malayu.S.P. (2012). Manajemen Sumber Daya Manusia. Jakarta: PT. Bumi Aksara. 
Hoki, Leony., \& Sofyan, Silvia. (2019). Pengaruh Kompetensi Sumber Daya Manusia dan Kedisiplinan terhadap Kinerja Karyawan PT. Sumber Sukses Rezeki. Jurnal Ilmiah Smart Volume III No.1, Juni 2019 Hal : 22 - 25.

Irawati, Rusda Dini., \& Carollina, Arimbi. (2017). Analisis Pengaruh Beban Kerja Terhadap Kinerja Karyawan Operator Pada PT Giken Precision Indonesia. Inovbiz: Jurnal Inovasi dan Bisnis, Vol. 5, No. 1, Juni 2017, hlm. 53-58.

ISS Indonesia. (2020). https://www.id.issworld.com/ dan https://id.edit.issworld.com diakses pada November 2020.

Kurniasari, Novira. (2014). Hubungan Disiplin Kerja, Lingkungan Kerja dan Kompensasi derhadap Kepuasan Kerja dan Kinerja Pada Pegawai Politeknik Kesehatan. Jurnal Ekonomi Manajemen Sumber Daya Vol. 15, No. 2, Desember 2014.

Kusuma, Aster Andriani,. \& Soesatyo, Yoyok. (2014). Pengaruh Beban Kerja terhadap Stres Kerja dan Dampaknya terhadap Kinerja Karyawan. Jurnal Ilmu Manajemen, Volume 2 Nomor 2 April 2014.

Mangkunegara, A.A. Anwar Prabu. (2016). Manajemen Sumber Daya Manusia Perusahaan. Cetakan Ketigabelas. Bandung: PT Remaja Rosdakarya.

Moniharapon, Stefy. (2018). Analisis Pengaruh Budaya Organisasi, Kompetensi, dan Beban Kerja terhadap Kinerja Aparatur Sipil Negara (ASN) pada Kopertis Wilayah XII di Kota Ambon. Jurnal Manis Volume 2 Nomor 2.

Munandar, Ashar Sunyoto. (2014). Psikologi Industri dan Organisasi. Jakarta: Penerbit Universitas Indonesia.

Munandar, Ashar Sunyoto. (2014). Psikologi Kepribadian. Jakarta: PT Raja Grafindo Persada.

Mustapa, Zainuddin. (2018). Perilaku Organisasi Dalam Perspektif Manajemen Organisasi. Cetakan Pertama. Makassar: Celebes Media Perkasa.

Peraturan Menteri Dalam Negeri Nomor 12 Tahun 2008 Tentang Pedoman Analisis Beban Kerja di Lingkungan Departemen Dalam Negeri dan Pemerintah Daerah.

Robbins, S.P. \& Judge, T.A. (2015). Perilaku Organisasi, Organizational Behavior Edisi 16. Terjemahan: Saraswati, Ratna. \& Sirait, Febriella. Jakarta: Salemba Empat. 
Salwa, Arfah., Away, Yuwaldi., \& Tabrani, Mirza. (2018). Pengaruh Komitmen, Integritas dan Kompetensi terhadap Kinerja Pegawai Serta Dampaknya pada Kinerja Komisi Independen Pemilihan (KIP) Aceh. Jurnal Magister Manajemen Fakultas Ekonomi dan Bisnis Unsyiah pp. 58-67 Volume 2, No. 1, Januari 2018.

Soelton, Mochamad., \& Rahmi, Rizky Andrafiana. (2016). Pengaruh Penerapan Kaizen dan Disiplin Kerja terhadap Kinerja Karyawan di Departemen Customer Service PT BCA Finance. Jurnal Ilmiah Manajemen Dan Bisnis Volume 2, Nomor 3.

Sugiyono. (2017). Metode Penelitian Kuantitatif, Kualitatif dan R\&D. Bandung: Alfabeta.

Sukaini,. Mattalatta,. \& Akmal. (2018). Pengaruh Karakteristik Individu, Beban Kerja dan Lingkungan Kerja Terhadap Kinerja Karyawan Pada PT. Sirkulasi Kompas Gramedia Makassar. YUME: Journal of Management Vol 1, No 1 (2018).

Sutrisno, Edy. (2018). Budaya Organisasi. Cetakan ke-5 Edisi Pertama. Jakarta: Prenadamedia Group.

Yamanie, Ibnu Yarham., \& Y, Syaharuddin. (2016). Pengaruh Penilaian Prestasi Kerja, Komitmen Organisasi dan Disiplin Kerja terhadap Kinerja Karyawan pada PT. Pelabuhan Indonesia IV Cabang Samarinda. Jurnal Manajemen, Volume 8, (1).

Yudiningsih, Ni Made Diah., Yudiaatmaja, Fridayana., \& Yulianthini, Ni Nyoman,. (2016). Pengaruh Lingkungan Kerja dan Disiplin Kerja terhadap Kinerja Pegawai (Studi pada Distanak Kabupaten Buleleng). Jurnal Manajemen.Vol 4 No.1. Universitas Pendidikan Ganesha. 